\title{
The Role of Life Satisfaction and Volunteering Frequency in Predicting Youth Contribution to Self, Family and Community
}

\author{
Inga Truskauskaitè-Kunevičienè ${ }^{1}$ \\ ${ }^{1}$ Mykolas Romeris university, Vilnius, Lithuania \\ Correspondence: Inga Truskauskaitè-Kunevičienė, Mykolas Romeris university, Ateities st. 20, Vilnius, \\ LT-08303, Lithuania. Tel: 370-5-271-4739. E-mail: inga.truskauskaite@mruni.eu
}

Received: August 6, 2014

Accepted: December 2, $2014 \quad$ Online Published: February 17, 2015

doi:10.5539/ijps.v7n1p51

URL: http://dx.doi.org/10.5539/ijps.v7n1p51

\begin{abstract}
This study aims to explore relationships between life satisfaction, volunteering frequency and contribution to self, family and community for youth in Lithuania and to compare these relationships for boys and girls. Data from a two-wave longitudinal study of a youth community sample was used. The sample size for this study was $\mathrm{N}=$ 1,140 (52.7\% girls and $47.3 \%$ boys). The age of participants ranged from 14 to 19 at T1 (Mage=16.61, SDage $=1.24$ at T1) and from 15 to 19 at T2 (Mage=17.1, SDage=0.93 at T2). Structural equation modeling (SEM) was used to measure and analyze the relationships of observed and latent variables. The results indicate that life satisfaction and volunteering frequency positively predict contribution to self, family (for boys only) and community.
\end{abstract}

Keywords: life satisfaction, volunteering, contribution, positive youth development

\section{Introduction}

Contribution to self, family and community is seen as a desirable outcome of youth's positive development and is conceptualized through persons active participation in the individual $<_{-}>$context interaction, which leads to the regulation and promotion of owns further positive development (Lerner et al. 2005). This is the reason why among other important goals such as promoting Five C's of positive youth development (Confidence, Competence, Caring, Connection and Character), active contributions are likely to take an important place in youth development programs (Roth \& Brooks-Gunn, 2003).

It has been shown that successful youth's development is positively linked to the contributions in the community (Jelicic, Bobek, Phelps, Lerner, \& Lerner, 2007; Lerner, Bowers, Geldhof, Gestsdóttir, \& DeSouza, 2012). However in the intervention programmes aimed at promoting positive youth development we can find a wide range of activities, from sports to unstructured leisure activities, suggesting the ways, how to strengthen youth so they can take an active part in promoting their own development (Catalano, Berglund, Ryan, Lonczak, \& Hawkins, 2004). Some of these activities are provided by volunteering-based organisations (e.g., Big Brothers Big Sisters, 4-H) and it was found to be beneficial and ensuring stable positive outcomes for participating youth as well for the volunteers themselves (Stukas, Daly, \& Clary, 2006). This suggests the idea that volunteering activities could also lead to positive youth development and could be used not only for supporting youth, but also for engaging them in direct active participation for their own well-being.

Community psychology approach also emphasizes that active civic participation such as volunteering activities should lead to increased sense of belonging and empowerment (Wanderman \& Florin, 2000; Sherrod, Torney-Purta, \& Flanagan, 2010) as well as to many other positive outcomes. However, research trying to find supportive empirical evidence for these ideas (especially with youth) is just starting to emerge. Researchers recently found that organizational membership of volunteering is significant in promoting youth's social well-being directly as well as through the increased sense of community and empowerment (Cicognani, Mazzoni, Albanesi, \& Zani, 2014). However, empirical evidence, showing relationships between volunteering activities and contribution to self, family and community is highly limited.

The other topic considered in this study is the relationship between subjective well-being and positive contributions. Subjective well-being is to be conceptualized through life satisfaction and is considered as cognitive component of subjective well-being (Diener, 1994). Recent research shows positive links between 
positive youth development and life satisfaction (Sun \& Sheck, 2010, 2012; Mohamad, Mohammad, \& Ali, 2014; Truskauskaitè-Kunevičienè, Žukauskienė, \& Kaniušonytė, 2014b). It is even argued that life satisfaction plays important role in positive youth development as an indicator, predictor, mediator/moderator and outcome (Park, 2004). In addition, as theoretically conceptualized, promoting positive youth development should lead to increased well-being and thriving (Roth \& Brooks-Gunn, 2003; Lerner et al., 2005). In addition, well-being itself could be indexed through Five C's of positive youth development (Confidence, Competence, Caring, Connection and Character) and the "sixth C"-Contribution (Lerner, Dowling, \& Anderson, 2003). Therefore, we can expect that life satisfaction, as a cognitive component of well-being, should also lead to increased contribution.

It is to notice, that Contribution is conceptualized as behavioral and ideological positive contributions to self, family, community and civil society (Lerner et al., 2005). However, most studies focus on community aspect (e.g. Jelicic et al., 2007; Gestsdóttir \& Lerner, 2007; Scarbrough, 2013) and it has been never questioned before how life satisfaction or pro-social activities such as volunteering are related to different aspects of contribution, namely, contribution to self, to family and to community. Therefore this study aims to investigate longitudinal and cross-sectional relationships between life satisfaction, volunteering frequency and contribution to self, family and community for youth aged from 15 to 19 , taking into account possible gender differences.

\section{Method}

Data for this study was drawn from an ongoing longitudinal research project "Mechanisms of promoting positive youth development in the context of socio-economical transformations (POSIDEV)" conducted in Northeastern Lithuania. The community sample consists of all 9 to 12 grades students from five high schools in Utena district municipality. This district was chosen because it represents well the Lithuanian population distribution. Families that reside in the neighborhoods' in which these schools are located are diverse in terms of family and socio-economic backgrounds. Among the participants, $65.9 \%$ lived with both parents; the rest had a range of other family situations due to parental divorce $(18.7 \%)$, loss $(5.1 \%)$, migration $(3.7 \%)$, or other reasons. With regard to the socio-economic status, $22.8 \%$ received state economic support (free nutrition at school), and in $21.7 \%$ of cases at least one of the parents was jobless. The sample is homogeneous in terms of their ethnic and cultural backgrounds (absolute majority of the participants were Lithuanian). The data is collected with a 1-year interval. A total of 1,787 students (participation rate-98.9\%) participated in the first assessment (T1). For this current study, only three younger cohorts (10-12 grades at second assessment (T2), N=1308, participation rate-99.1\%) and only the participants who filled all relevant measures were included in the analyses. Thus, the sample size for this study was $\mathrm{N}=1,140$ (52.7\% girls and $47.3 \%$ boys). The age of participants ranged from 14 to 19 at $\mathrm{T} 1(\mathrm{Mage}=16.61, \mathrm{SDage}=1.24$ at T1) and from 15 to 19 at T2 $(\mathrm{Mage}=17.1, \mathrm{SDage}=0.93$ at T2).

Life Satisfaction was measured with the Satisfaction with life scale (Diener at el., 1995). The authors allow translating and using this scale without the permission. The Lithuanian version from previous studies conducted in Lithuania (e.g. Šilinskas \& Žukauskienè, 2004) was used. Cronbach's alphas for this sample at T1 and T2 were respectively .84 and .85 . The single factor structure was confirmed in this sample.

Volunteering Frequency was measured with single item 6-points scale, which indicates how often (from 1-never to 6-every day) participants engage in volunteering activities.

Contribution to Self, Family and Community was measured with a newly developed Three-dimensional Contribution Scale (Truskauskaitė-Kunevičienè, Kaniušonyte, \& Žukauskienè 2014a), which consists of three subscales: Contribution to Self (e.g. I engage in activities that help me improve), Contribution to Family (e.g. I often show interest in how are my family members doing) and Contribution to Community (e.g. I try to be a good example for other members of the community). The scale was created and provided in Lithuanian language. Cronbach's alphas in this sample for three subscales at T2 were respectively $.87, .81$, and .92 . The authors of the scale confirmed the three-dimensional factor structure (CFA results: $\chi 2 / \mathrm{df}=3.17, \mathrm{CFI}=.91$, RMSEA $=.08$ ) and concurrent validity (Truskauskaitè-Kunevičienè et al., 2014a).

A structural Equation Model (SEM) analysis was conducted using Mplus 6.12.

\section{Results}

The tested model consisted of five latent variables: Life Satisfaction at T1 and T2, Contribution to Self, Contribution to Family and Contribution to Community at T2 and two observed variables: Volunteering Frequency at T1 and T2. Life Satisfaction and Volunteering Frequency at T1 were regressed on all other variables (except on each other). 
3.1 The Relationship between Life Satisfaction, Volunteering Frequency and Contribution to Self, Family and Community for both Genders

Model fit indices indicated that the model (see Figure 1.) fitted data reasonably well $(\chi 2 / \mathrm{df}=4.99$, CFI/TLI $=.92 / .91$, RMSEA $=.063[.060-.066])$, thus we can conclude, that both variables-Life Satisfaction and Volunteering Frequency are important in predicting Contribution to Self, Family and Community.

Model results indicated, that neither Life satisfaction, nor Volunteering frequency predict each other. However both variables at $\mathrm{T} 1$ significantly predict all three dimension of Contribution at $\mathrm{T} 2$.

Life Satisfaction has higher scores in predicting Contribution to Self and Family than to Community and Volunteering Frequency-in predicting Contribution to Community, than to Contribution to Self and Contribution to Family. Life Satisfaction also shows higher stability in the period of one year.

Cross-sectional correlational relationships analysis between Life satisfaction and Contribution revealed the same pattern of linkage as in longitudinal perspective. However Volunteering was strongly related to Contribution to Community, weaker to Contribution to Self and not related to Contribution to Family.

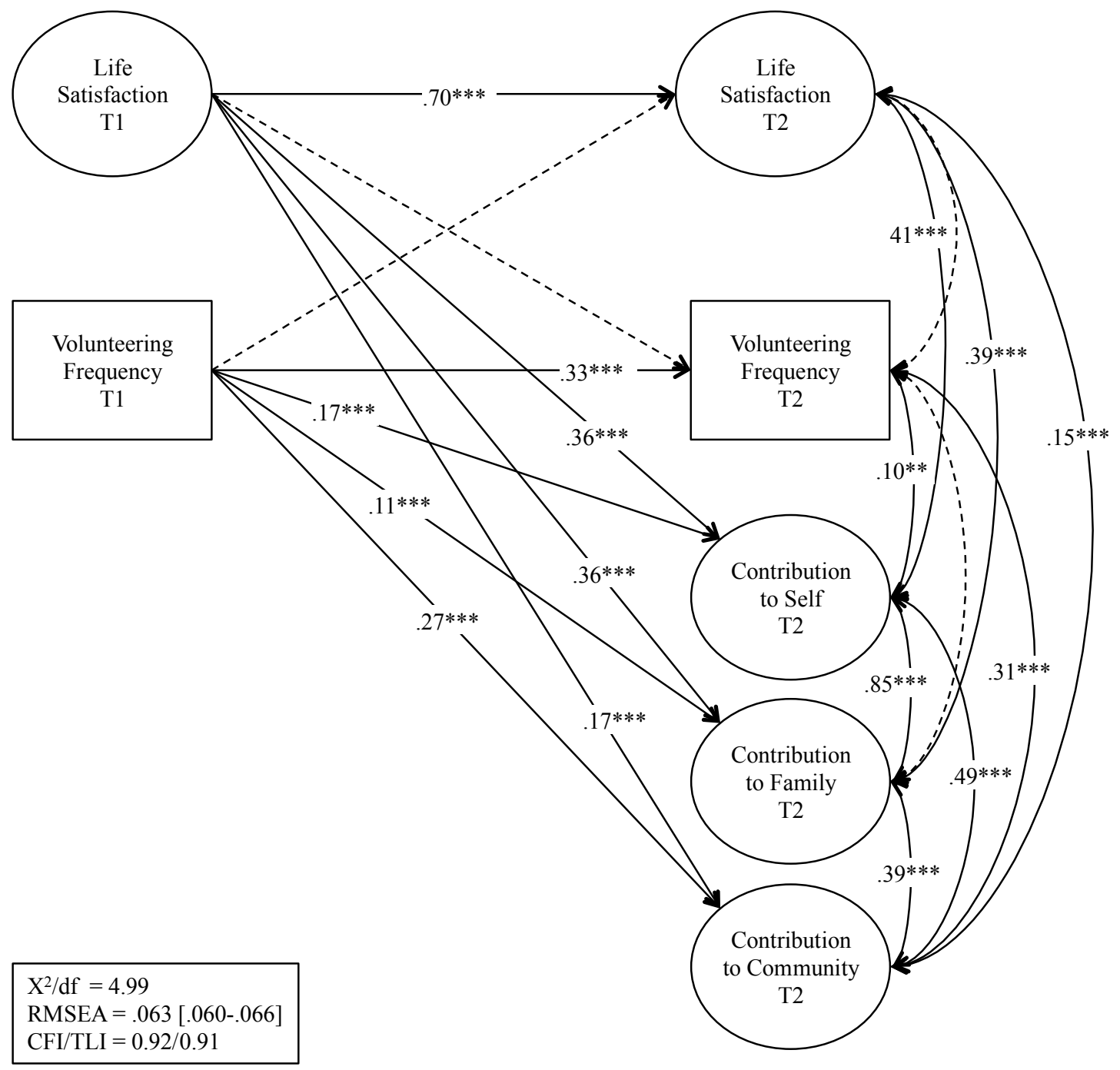

Figure 1. The relationship between life satisfaction, volunteering frequency and contribution to self, family and community for both genders 


\subsection{Gender Differences in the Relationship between Life Satisfaction, Volunteering Frequency and Contribution to self, Family and Community}

The grouping model was also tested to investigate whether there are any gender differences in predicting contribution to self, family and community by life satisfaction and volunteering frequency. Free and Fixed grouping models were tested. Whereas the Delta Chi-Square P-value was found to be significant at $\mathrm{p}<.05$ $(\mathrm{P}=.029)$, Free model, representing significant gender differences (see Figure 2. and Figure 3.), was chosen. The model fitted data even better than the model for both genders $(\chi 2 / \mathrm{df}=3.51, \mathrm{CFI} / \mathrm{TLI}=.91 / .90, \mathrm{RMSEA}=.066$ [.063-.069]), thus we can conclude, that life satisfaction and volunteering frequency are important in predicting contribution to self, family and community both for boys and for girls, but the relationship between these variables are slightly different for different genders.

The Free model findings indicated, that Volunteering Frequency does predict Life Satisfaction neither for boys nor for girls. Life satisfaction does not predict Volunteering Frequency for girls, though Life satisfaction is a week but significant predictor of Volunteering frequency for boys.

In predicting Contribution by Life Satisfaction, both genders show the same pattern as in the common model: Life Satisfaction has higher regression coefficients in predicting Contribution to Self and Family, than to Community. However in all cases these relationships are stronger for girls, than for boys. In case of Community Contribution, the prediction for girls is much stronger and even more significant than for boys.

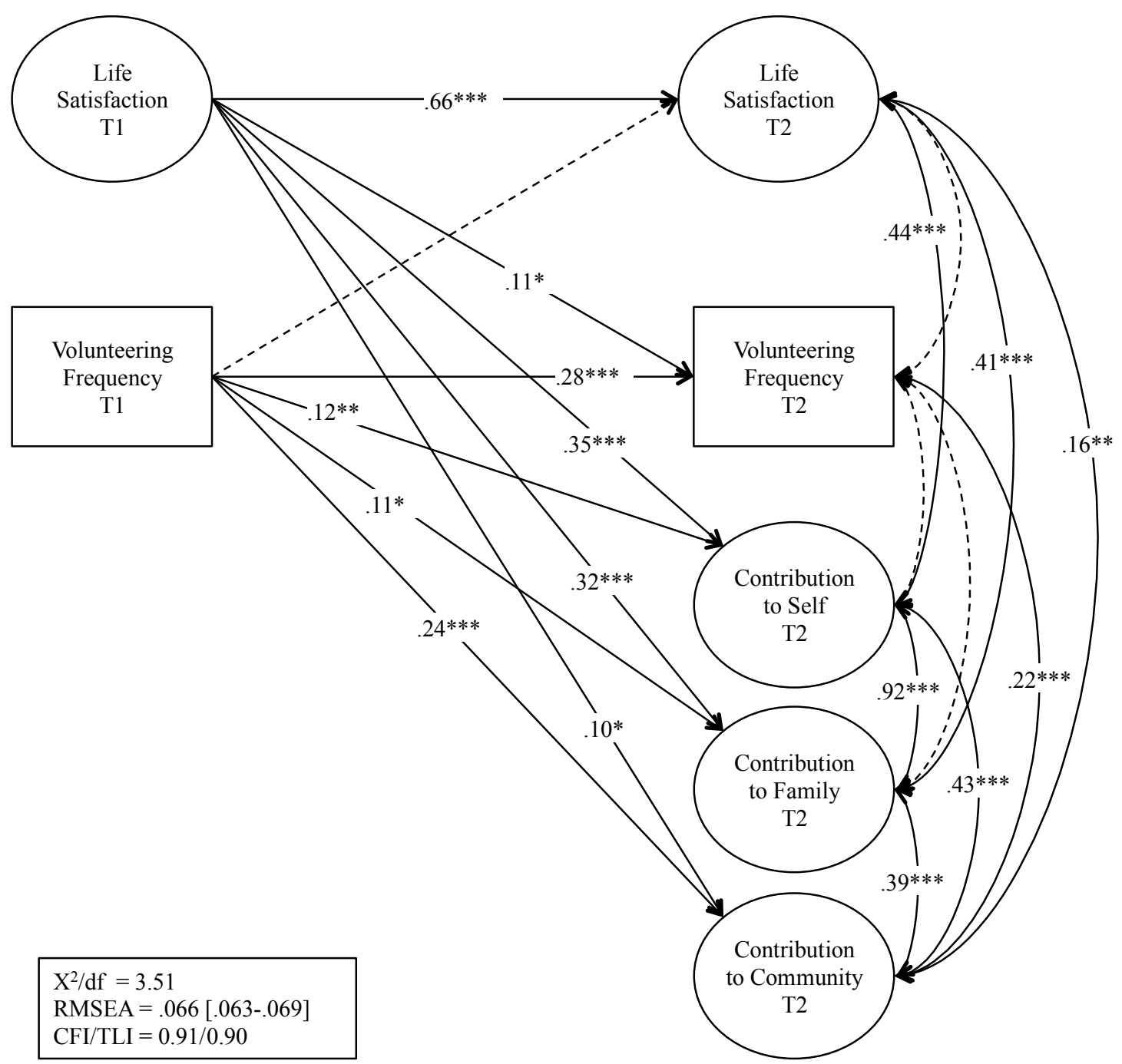

Figure 2. The relationship between life satisfaction, volunteering frequency and contribution to self, family and community for boys 
We also find the similar pattern in predicting Contribution to o Self and to Community by Volunteering Frequency for both genders: Volunteering Frequency is a stronger predictor for Contribution to Community, than for Contribution to Self. The regression coefficients for girls in both cases are again higher than for boys. However we find a gender difference in predicting Contribution to Family. In a boys' case Volunteering frequency is a week but significant predictor for Contribution to Family, while there is no such a relationship in a girls' case.

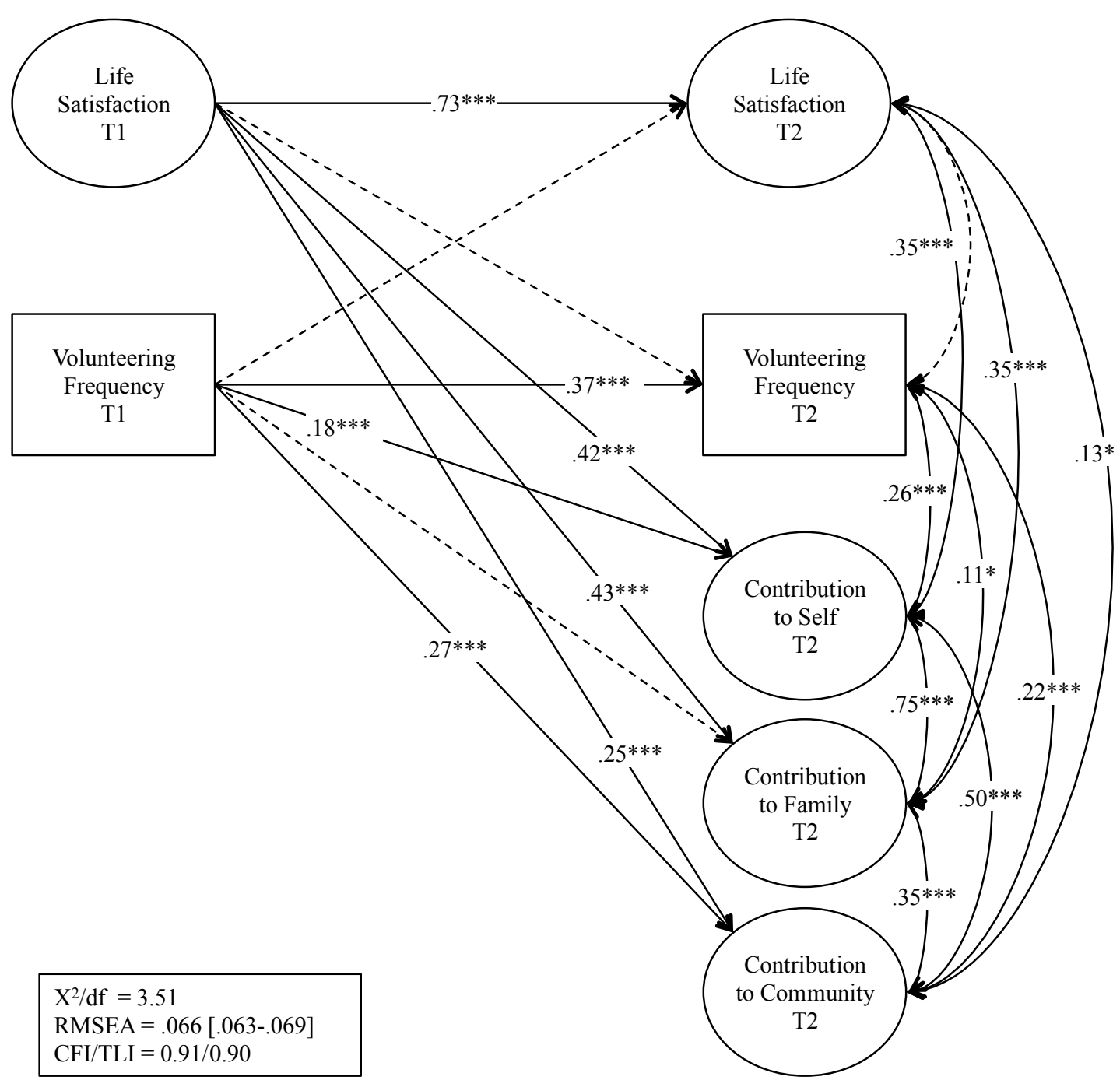

Figure 3. The relationship between life satisfaction, volunteering frequency and contribution to self, family and community for girls

We did not find any cross-sectional correlational links between Life Satisfaction and Volunteering Frequency neither for boys nor for girls.

A correlational relationship between Life Satisfaction and Contribution shows the similar patterns for boys and for girls. As for the predicting relationship, Life Satisfaction has stronger links to Contribution to Self and Family, than to Contribution to the Community. These links are stronger for boys than for girls. In case of relationship between Life Satisfaction and Contribution to Community, the correlation for girls is less significant than for boys.

The analysis of correlational relationship between Volunteering Frequency and Contribution revealed, that there are no links between Volunteering Frequency and Contribution to Self and to Family for boys, whereas findings indicated these links for girls. However in the girls' case the relationship between Volunteering Frequency and 
Contribution to Self is much stronger and more significant, than relationship between Volunteering Frequency and Contribution to Family.

\section{Discussion}

This study aimed to analyze longitudinal and cross-sectional relationships between life satisfaction, volunteering frequency and contribution to self, family and community for youth aged from 15 to 19 , taking into account possible gender differences. Structural equation modeling was used for testing these relationships.

It was found, that increased life satisfaction does not lead to increase of volunteering frequency (at least for girls), however, as expected, it leads to increased active participation (contribution) in one's self's, family's and community's lives. These findings are consistent with positive youth development theory (Roth \& Brooks-Gunn, 2003; Lerner at al., 2005).

The unexpected finding, that there are no significant links between life satisfaction and volunteering frequency could be explained through functionalist theory. This theory argues that people can perform the same actions, seeking to fulfill different goals or different psychological needs (Katz, 1960). Functionalist theory was used for explaining volunteering activities and it was proposed, that different people could have different motives for starting and continuing volunteering (Clary at al., 1998). This could mean that people engage in volunteering activities because of lack of something (e.g. social ties, knowledge or skills) as well because of excess of something (e.g. desire to express personal values or consolidate ones ego). Usually dissatisfaction with life is associated with lack of something and satisfaction-contrary-with "having what I want". Taking into account the volunteering motives suggested by Clary at al. (1998) we can indicate, that our findings are consistent with the idea that both states (satisfaction and dissatisfaction) can motivate volunteering. However this study shows that for boys there is a predictive relationship between life satisfaction and volunteering frequency. This could mean, that if we want to motivate boys for volunteering, satisfaction motives are more important for them than motives related to lack of something. Whereas for girls both types of motives could be of the same importance. However this should be tested in further studies.

It was also found, that increased volunteering frequency does not lead to increase of life satisfaction, however, as expected, it leads to increased contribution to self, family (only for boys) and community. This is consistent with recent findings, that volunteering predicts youth's social well-being (Cicognani et al., 2014), which, as conceptualized by Keyes (1998), among other important dimensions, include social contributions.

Gender differences in longitudinal relationship between volunteering frequency and contribution to family could be explained through to gender roles in family lives. From the previous studies we know, that girls generally show more nurturing activities than boys (Lippa, 2005). Girls also tend to engage more in family lives than boys (Raley \& Bianchi, 2006). This could mean, that girls tend to contribute more to family, than boys. Our findings suggest that engagement in volunteering activities probably does not change anything in girls' family involvement. However for boys this engagement can promote higher contributions to family life.

Present-time correlational links analysis indicated the same absence of relationship between life satisfaction and volunteering frequency and the same positive relationship between life satisfaction and contribution to self, family and community as in longitudinal perspective. However we found interesting results in the present-time relationships between volunteering frequency and contribution. Although we cannot tell the direction of the relationship, we can see, that those girls and boys who contribute to community more, volunteer more frequently (or those who volunteer more frequently, contribute to community more). However we do not find this for both genders in case of contribution to self and to family. The results revealed, that those girls, who demonstrate more engagement to one self's and family's well-being, volunteer more often (or those who volunteer more, contribute to self and to family more). There is no such a relationships for boys. Therefore we can expect that girls tend to engage actively in more different fields and boys' active engagement in one field does not necessary mean the engagement in the other field.

Overall, this study has some relevant practical implications. According to the results, it could be suggested, that youth development programs, aiming to foster contribution to self, family and community could reach this goal through increasing participants life satisfaction. In addition it can be suggested, that promotion of volunteering activities is a good way to promote future positive contributions to self, family and community. The volunteering activities are not yet of much popularity in Lithuania. Investment and effort trying to change it could give desirable results in terms of active youth participation. 
The limitation of this study concerns the two-wave longitudinal design. The longer time perspective could give the better picture of the relationship between life satisfaction, volunteering frequency and contribution to self, family and community.

\section{Conclusion}

This study highlighted that both life satisfaction and volunteering frequency are important in predicting higher contributions to self, family and community for youth in Lithuania. Thus it can be concluded, that increasing youths well-being (or positive development) as well engaging them in volunteering activities can enhance their active participation and regulation of one's self, family and community well-being either it can promote their further positive development.

This study also revealed, that although the promotion of life satisfaction and volunteering could be beneficial for youth of both genders, efforts to increase boys' life satisfaction can also increase their engagement in volunteering activities as well as engaging in volunteering could increase boys' more active participation in families' lives.

\section{Acknowledgments}

This research is/was funded by the European Social Fund under the Global Grant measure, VP1-3.1-ŠMM-07-K-02-008.

This article was written under the supervision of prof. Rita Žukauskienė, Mykolas Romeris university, Lithuania.

\section{References}

Catalano, R. F., Berglund, M. L., Ryan, J. A., Lonczak, H. S., \& Hawkins, J. D. (2004). Positive youth development in the United States: Research findings on evaluations of positive youth development programs. The annals of the American academy of political and social science, 591(1), 98-124. http://dx.doi.org/10.1177/0002716203260102

Cicognani, E., Mazzoni, D., Albanesi, C., \& Zani, B. (2014). Sense of Community and Empowerment Among Young People: Understanding Pathways from Civic Participation to Social Well-Being. VOLUNTAS: International Journal of Voluntary and Nonprofit Organizations, 1-21. http://dx.doi.org/10.1007/s11266-014-9481-y

Clary, E. G., Snyder, M., Ridge, R. D., Copeland, J., Stukas, A. A., Haugen, J., \& Meine, P. (1998). Understanding and assessing the motivations of volunteers: A functional approach. Journal of Personality and Social Psychology, 74, 1516-1530. http://dx.doi.org/10.1037/0022-3514.74.6.1516

Diener, E. (1994). Assessing subjective well-being: Progress and opportunities. Social indicators research, 31(2), 103-157. http://dx.doi.org/10.1007/BF01207052

Gestsdóttir, S., \& Lerner, R. M. (2007). Intentional self-regulation and positive youth development in early adolescence: Findings from the 4-h study of positive youth development. Developmental psychology, 43(2), 508. http://dx.doi.org/10.1037/0012-1649.43.2.508

Jelicic, H., Bobek, D. L., Phelps, E., Lerner, R. M., \& Lerner, J. V. (2007). Using positive youth development to predict contribution and risk behaviors in early adolescence: Findings from the first two waves of the 4-H Study of Positive Youth Development. International Journal of Behavioral Development, 31(3), 263-273. http://dx.doi.org/10.1177/0165025407076439

Katz, D. (1960). The functional approach to the study of attitudes. Public opinion quarterly, 24(2), 163-204. http://dx.doi.org/10.1086/266945

Keyes, C. L. M. (1998). Social well-being. Social psychology quarterly, 121-140. Retrieved from http://www.jstor.org/stable/2787065

Lerner, R. M., Bowers, E. P., Geldhof, G. J., Gestsdóttir, S., \& DeSouza, L. (2012). Promoting positive youth development in the face of contextual changes and challenges: The roles of individual strengths and ecological assets. New directions for youth development, 2012(135), 119-128. http://dx.doi.org/10.1002/yd.20034

Lerner, R. M., Dowling, E. M., \& Anderson, P. M. (2003). Positive youth development: Thriving as the basis of personhood and civil society. Applied Developmental Science, 7(3), 172-180. http://dx.doi.org/10.1207/S1532480XADS0703_8 
Lerner, R. M., Lerner, J. V., Almerigi, J. B., Theokas, C., Phelps, E., Gestsdottir, S., ... von Eye, A. (2005). Positive Youth Development, Participation in community youth development programs, and community contributions of fifth-grade adolescents findings from the first wave Of the 4-H study of Positive Youth Development. The Journal of Early Adolescence, 25(1), 17-71. http://dx.doi.org/10.1177/0272431604272461

Lippa, R. A. (2005). Gender, nature, and nurture. Routledge.

Mohamad, M., Mohammad, M., \& Ali, N. A. M. (2014). Positive Youth Development and Life Satisfaction among Youths. Journal of Applied Sciences, 14(21), 2782-2792. Retrieved from http://docsdrive.com/pdfs/ansinet/jas/2014/2782-2792.pdf

Park, N. (2004). The role of subjective well-being in positive youth development. The Annals of the American Academy of Political and Social Science, 591(1), 25-39. http://dx.doi.org/10.1177/0002716203260078

Raley, S., \& Bianchi, S. (2006). Sons, daughters, and family processes: Does gender of children matter? Annual Review of Sociology, 401-421. Retrieved from http://www.jstor.org/stable/29737745

Roth, J. L., \& Brooks-Gunn, J. (2003). What exactly is a youth development program? Answers from research $\begin{array}{llll}\text { and } \quad \text { practice. } & \text { Applied developmental }\end{array}$ http://dx.doi.org/10.1207/S1532480XADS0702_6

Scarbrough, S. (2013). Positive Youth Development and Substance Use in Emerging Adults. McNair Scholars Research Journal, 9(1), 61-66. http://scholarworks.boisestate.edu/monair_journal/vol9/iss1/12

Sherrod, L., Torney-Purta, J., \& Flanagan, C. (Eds.). (2010). Handbook of research on civic engagement in youth. Hoboken, NJ: Wiley. http://dx.doi.org/10.1002/9780470767603.fmatter

Šilinskas, G., \& Žukauskienė, R. (2004). Subjektyvios gerovès išgyvenimas ir su juo susiję veiksniai vyrų imtyje. Psichologija, 30, 47-58. Retrieved from http://rzukausk.home.mruni.eu/wp-content/uploads /Silinskas-Zukauskiene-2004.pdf

Stukas, A. A., Daly, M., \& Clary, E. G. (2006). Lessons from research on volunteering for mobilizing adults to volunteer for positive youth development. In Mobilizing adults for positive youth development (pp. 65-82). Springer. http://dx.doi.org/10.1007/0-387-29340-X_4

Sun, R. C., \& Shek, D. T. (2010). Life satisfaction, positive youth development, and problem behaviour among Chinese adolescents in Hong Kong. Social Indicators Research, 95(3), 455-474. http://dx.doi.org/10.1007/s11205-009-9531-9

Sun, R. C., \& Shek, D. T. (2012). Positive youth development, life satisfaction and problem behaviour among Chinese adolescents in Hong Kong: A replication. Social indicators research, 105(3), 541-559. http://dx.doi.org/10.1007/s11205-011-9786-9

Truskauskaitè-Kunevičienė, I., Kaniušonytè, G., \& Žukauskienė, R. (2014a). What Does it Mean to 'Contribute' in an Eastern-European Context? The Development and Psychometrical Evaluation of the new Scale. Conference Paper, SRCD's Special Topic Meeting "Positive Youth Development (PYD) in the Context of the Global Recession”, At Prague, Czech Republic.

Truskauskaitė-Kunevičienė, I., Žukauskienė, R., \& Kaniušonytė, G. (2014b). Positive Youth Development Links to Satisfaction with life, Resilience and Internalizing and Externalizing Problems. Social Work, 13(1), 98-109. http://dx.doi.org/10.13165/SD-14-13-1-06

Wandersman, A., \& Florin, P. (2000). Citizen participation and community organizations. In J. Rappaport, \& E. Seidman (Eds.), Handbook of community psychology. New York: Plenum. http://dx.doi.org/10.1007/978-1-4615-4193-6_11

\section{Copyrights}

Copyright for this article is retained by the author(s), with first publication rights granted to the journal.

This is an open-access article distributed under the terms and conditions of the Creative Commons Attribution license (http://creativecommons.org/licenses/by/3.0/). 